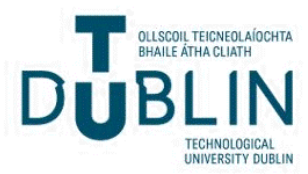

Technological University Dublin ARROW@TU Dublin

2011-01-01

\section{Differential Precipitation and Solubilization of Proteins.}

\author{
Barry Ryan \\ Technological University Dublin, barry.ryan@tudublin.ie
}

Follow this and additional works at: https://arrow.tudublin.ie/schfsehbk

Part of the Biochemistry Commons, Biotechnology Commons, Food Science Commons, and the Molecular Biology Commons

\section{Recommended Citation}

Ryan, B.J. (2011). Differential precipitation and solubilization of proteins. Methods in Molecular Biology (Eds. Loughran, S.T. and Walls, D.) Springer Protocols/Humana Press, NY, USA, pp. 203-213. doi:10.1007/ 978-1-60761-913-0_11

This Book Chapter is brought to you for free and open access by the School of Food Science and Environmental Health at ARROW@TU Dublin. It has been accepted for inclusion in Books/Book Chapters/ Proceedings by an authorized administrator of ARROW@TU Dublin. For more information, please contact arrow.admin@tudublin.ie, aisling.coyne@tudublin.ie, gerard.connolly@tudublin.ie.

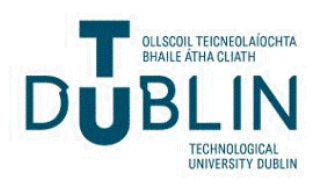




\section{Differential Precipitation and Solubilisation of Proteins.}

Barry J. Ryan

School of Food Science and Environmental Health, Dublin Institute of Technology, Cathal Brugha Street, Dublin 1, Republic of Ireland.

Email: barry.ryan@dit.ie

\section{Summary/Abstract}

Differential protein precipitation is a rapid and economical step in protein purification and is based on exploiting the inherent physico-chemical properties of the polypeptide. Precipitation of recombinant proteins, lysed from the host cell, is commonly used to concentrate the protein of choice before further polishing steps with more selective purification columns (e.g. His-Tag, Size Exclusion etc.). Recombinant proteins can also precipitate naturally as inclusion bodies due to various influences during over-expression in the host cell. Although this phenomenon permits easier initial separation from native proteins, these inclusion bodies must carefully be differentially solubilised so as to reform functional, correctly folded proteins. Here, a typical protein extraction, precipitation and selective resolubilisation procedure is outlined, based on a recombinantly expressed protein.

\section{Key Words}

Ammonium Sulphate precipitation, Trichloroacetic acid precipitation, inclusion body solubilisation, protein refolding. 


\section{Introduction}

Protein precipitation can be caused by the differential solubility between a protein-rich soluble phase and a solid chemical precipitant. Soluble proteins can be insolubilised by interaction with a suitable precipitant that decreases the protein's attraction to the solvent and increases the protein's attraction to other protein molecules, resulting in protein accumulation and eventually precipitation. The addition of low molecular weight substances, such as glycerol, polyethylene glycol and sucrose, and high molecular weight substances such as serum albumin, can have significant effects on protein structure and stability. Preferential hydration of a protein molecule caused by the presence of these additives can increase the protein's stability. Certain salts can also exert a stabilising effect by 'salting out' hydrophobic residues of a protein, causing the molecule to adapt a more compact, stable structure (1) frequently resulting in precipitation. The use of such protein precipitating molecules is an empirical process, the effects of any given substance on a protein must be determined experimentally. The use of additives can not only be used as a simple approach to increase the stability of a given protein, but also to actively effect protein precipitation. Protein precipitation can be used as a crude protein clean-up method from cell lysates, readily employed after bacterial over-expression of recombinant proteins.

Differential solubilisation of proteins is often employed for proteomic analyses $(2,3)$, but it too can offer an alternative purification technique for non-soluble recombinant proteins expressed in heterologous hosts. Recombinant proteins expressed as inclusion bodies can be readily separated from the host cell protein matrix, however careful solubilisation and refolding are critical for 
obtaining suitable recombinant proteins for further downstream processes. Here a typical recombinant protein precipitation and resolubilisation procedure is outlined.

\section{Materials}

Note: All consumables may be sourced from Sigma-Aldrich unless otherwise stated.

\subsection{Recombinant / Native Protein Extraction.}

1. Centrifuge (Bucket Type, e.g. J2-21, Beckman and microfuge, e.g. 5415D Eppendorf).

2. $\mathrm{pH}$ meter (e.g. $M-240$, Corning).

3. Sonicator (e.g. Vibra Cell, Sonics Scientific).

4. Water bath (temperature controlled).

5. Vortex.

6. Resuspension Buffer One: $50 \mathrm{mMNa} \mathrm{NPO}_{4}-\mathrm{NaH}_{2} \mathrm{PO}_{4}, \mathrm{pH} 8.0,0.3 \mathrm{M} \mathrm{NaCl}$.

7. $-80^{\circ} \mathrm{C}$ freezer

\subsection{Protein Precipitation using Ammonium Sulphate.}

1. Resuspension Buffer One: $50 \mathrm{~m} M \mathrm{Na}_{2} \mathrm{HPO}_{4}-\mathrm{NaH}_{2} \mathrm{PO}_{4}, \mathrm{pH} 8.0,0.3 \mathrm{M} \mathrm{NaCl}$.

2. Saturated Ammonium Sulphate: Add $750 \mathrm{~g}$ of $\left(\mathrm{NH}_{4}\right)_{2} \mathrm{SO}_{4}$ to $1 \mathrm{~L}$ of double distilled water in a beaker or flask. Stir the solution at room temperature with a magnetic stirrer for 15 
min or until saturation. Gently decant the clear supernatant solution after the undissolved solids settle on the bottom of the flask.

3. Graduated Pipette $(10 \mathrm{~mL})$.

\subsection{Protein Precipitation using Trichloroacetic acid.}

1. $2 \%$ Deoxycholate (DOC): Add $2 \mathrm{~g}$ of DOC to $100 \mathrm{~mL}$ of double distilled $\mathrm{H}_{2} \mathrm{O}$, mix well.

2. $100 \%$ Trichloroacetic acid (TCA): Add $1 \mathrm{~g}$ of TCA to $454 \mu \mathrm{L}$ double distilled $\mathrm{H}_{2} \mathrm{O}$ and mix carefully. Store in a light proof bottle at $4^{\circ} \mathrm{C}$ until required for use. TCA is a harmful skin and eye irritant. Always use correct personal protective equipment when handling it.

3. Acetone (ice cold). Store acetone at $-20^{\circ} \mathrm{C}$. Use directly from $-20^{\circ} \mathrm{C}$.

4. Vacuum Dryer (e.g. DNA 110 Speed Vac, Savant)

5. Resuspension Buffer: $50 \mathrm{mMNa} \mathrm{NPO}_{4}-\mathrm{NaH}_{2} \mathrm{PO}_{4}, \mathrm{pH} 8.0,0.3 M \mathrm{NaCl}$.

6. Centrifuge (Bucket Type, e.g. J2-21, Beckman and microfuge, e.g. 5415D Eppendorf).

\subsection{Protein Solubilisation.}

1. DNase I (100 U/mL).

2. Resuspension Buffer Two: $50 \mathrm{~m} M \mathrm{Na}_{2} \mathrm{HPO}_{4}-\mathrm{NaH}_{2} \mathrm{PO}_{4}, \mathrm{pH}$ 8.0, $0.3 M \mathrm{NaCl}, 5 \mathrm{~m} M$ DTT, $0.35 \mathrm{mg} / \mathrm{mL}$ Lysozyme, Proteinase Inhibitor Cocktail (see also Chapter 4). Make up as fresh prior to use.

3. Triton X-100. 
4. Solubilisation Buffer: $50 \mathrm{~m} M \mathrm{Na}_{2} \mathrm{HPO}_{4}-\mathrm{NaH}_{2} \mathrm{PO}_{4}, \mathrm{pH}$ 8.0, $0.3 M \mathrm{NaCl}, 25 \mathrm{~m} M$ DTT, 6 $M$ Guanidine $\mathrm{HCl}$.

5. PBS-T: Phosphate buffered saline (PBS, 1x) containing $1 \%$ Triton $\mathrm{X}-100$.

6. Centrifuge (Bucket Type, e.g. J2-21, Beckman and microfuge, e.g. 5415D Eppendorf).

7. Vacuum Concentrator (Speed Vac, Savant)

\subsection{Protein Refolding.}

1. Refolding Buffer: $50 \mathrm{~m} M \mathrm{Na}_{2} \mathrm{HPO}_{4}-\mathrm{NaH}_{2} \mathrm{PO}_{4}, \mathrm{pH} 8.0,0.3 \mathrm{M} \mathrm{NaCl}, 2.5 \mathrm{~m} M$ reduced Glutathione, $0.25 \mathrm{~m} M$ Oxidized Glutathione, $0.2 \mathrm{M}$ Arginine.

2. Dialysis Buffer: $50 \mathrm{~m} M \mathrm{Na}_{2} \mathrm{HPO}_{4}-\mathrm{NaH}_{2} \mathrm{PO}_{4}, \mathrm{pH} 8.0,0.3 \mathrm{M} \mathrm{NaCl}$.

3. Dialysis apparatus (dialysis tubing and clips, magnetic mixer, large clean container).

4. Guanidine Hydrochloride: $6 M$ stock, made in double distilled $\mathrm{H}_{2} \mathrm{O}$.

5. Amicon protein concentration device (e.g. Ultra-15 Centrifugal Filter Units, Amicon).

6. Gradient maker apparatus (see Fig. 1). 


\section{Methods}

\subsection{Recombinant / Native Protein Extraction.}

The source of the protein will determine the optimal technique to release the protein from the tissue or cells in which it is contained. The typical freeze-thaw cell lysis procedure (below) is generally sufficient to lyse most bacterial cell types although other options are available (see Notes 1, 2, 3).

1. Collect the bacterial cells by transferring the bacterial culture to a pre-chilled sterile centrifuge tube and centrifuge at low speed $(5 \mathrm{~min}, 800 \mathrm{x} g$ ) in a previously cooled centrifuge $\left(4^{\circ} \mathrm{C}\right)$.

2. Carefully remove the culture media from the bacterial cell pellet, ensuring the pellet is not disturbed.

3. Resuspend the cell pellet in Resuspension Buffer One, in 10\% of the original culture volume.

4. Freeze the resuspended cells to $-80^{\circ} \mathrm{C}$ by placing the resuspension solution (still in the plastic centrifuge tube) into a pre-equilibrated $-80^{\circ} \mathrm{C}$ freezer, then warm the cells to $37^{\circ} \mathrm{C}$ (using a pre-equilibrated water bath) for $10 \mathrm{~min}$. Repeat this freeze thaw process three times. 
Sonication can also be used if the protein is not released during the freeze thaw steps. It is crucial to maintain the cell suspension on ice during the sonication process (see Notes $\mathbf{4 , 5}$,

6).

5. Sonicate at 10 amplitude microns for $10-20 \mathrm{~s}$.

6. Allow the cell suspension to stand on ice for $30 \mathrm{~s}$.

7. Repeat steps 5 and 6 three more times.

8. Check the recombinant protein induction/expression by loading and analysing a representative sample (typically $50 \mu \mathrm{g}$ protein) onto a SDS-PAGE gel.

\subsection{Protein Precipitation using Ammonium Sulphate.}

A common and inexpensive first step to isolate proteins during protein purification is precipitation with an external additive. This additive alters the physicohemical properties of the protein causing it to fall out of solution. Ammonium sulphate (see Note 7) is commonly used for large scale precipitations.

1. Gently stir the protein mixture with the aid of a magnetic stirring bar at $4^{\circ} \mathrm{C}$. Add, using a graduated pipette, the saturated ammonium sulphate solution drop-wise to the protein solution until precipitates start to form (see Notes $8,9, \mathbf{1 0}$ ).

2. Once sufficient saturated salt solution has been added to cause precipitation of the protein of interest (indicated by collection of precipitate at the bottom of the 
container), centrifuge the mixture at $10,000 \mathrm{~g}$ for $15 \mathrm{~min}$. Collect the precipitate by carefully discarding as much supernatant as possible (see Note 10).

3. Resuspend the protein pellet at $4^{\circ} \mathrm{C}$ in Resuspension Buffer One for further downstream processes.

\subsection{Protein Precipitation using Trichloroacetic acid.}

Trichloroacetic acid (TCA) is routinely employed for small scale operations or

precipitations of protein preparations that are at low concentration; however, it should be noted that this procedure is protein denaturing, and caution must be exercised when working with TCA (see Notes 11, 12).

1. To one volume of protein solution, add $1 / 100$ volume of $2 \%$ DOC (sodium deoxycholate).

2. Vortex and incubate for $30 \mathrm{~min}$ at $4^{\circ} \mathrm{C}$.

3. Add $1 / 10$ volume of $100 \%$ Trichloroacetic acid (TCA). Vortex the solution and incubate statically overnight at $4^{\circ} \mathrm{C}$.

4. Centrifuge the sample for $15 \mathrm{~min}$ at $4^{\circ} \mathrm{C}(10,400 \mathrm{x})$. Gently remove the supernatant and retain the pellet. Carefully dry the tube by inversion on tissue paper (note: the pellet may be difficult to see). 
5. Optional: Wash the pellet twice with one volume of ice-cold acetone. Vortex and re-pellet the samples by centrifugation $10,400 \times \mathrm{g}$ for $5 \mathrm{~min}$ at $4^{\circ} \mathrm{C}$ between washes (see Note 13).

6. Dry the samples under vacuum (e.g. Speed Vac, Savant) or allow to air dry.

7. Resuspend the protein pellet in a buffer of choice for further downstream processes. 


\section{4 Protein Solubilisation.}

Recombinant protein expression in a heterologous host frequently results in insoluble and inactive proteins. Regularly, protein overexpression results in the production of inclusion bodies, which are insoluble aggregates of misfolded protein. Although these inclusion bodies can easily be purified, further characterisation of this protein mass is often impossible without solubilisation of the protein of interest and refolding into an active form (see Note 14). A typical inclusion body solubilisation and refolding protocol is outlined below (see also Note 15):

1. Carry out steps 1-3 as outlined in 3.1, except resuspend the cell pellet in $10 \%$ of the original culture volume of Resuspension Buffer Two.

2. Slowly add Triton X-100 (to a final concentration of $1 \% \mathrm{v} / \mathrm{V}$ ), and mix gently.

3. Carry out the sonication procedure as outlined in 3.1 , steps $5-7$.

4. Incubate the cell debris with DNase $\mathrm{I}(100 \mathrm{U} / \mathrm{mL})$ for $1 \mathrm{~h}$ at $37^{\circ} \mathrm{C}$.

5. Collect the inclusion bodies by centrifugation at $30,000 \times \mathrm{g}$ for $30 \mathrm{~min}$ at $4^{\circ} \mathrm{C}$.

6. Wash the inclusion body pellet twice with PBS-T, followed by centrifugation at $30,000 \mathrm{~g}$ for $30 \mathrm{~min}$ at $4^{\circ} \mathrm{C}$.

7. Solubilise the pelleted inclusion bodies in the solubilisation buffer and allow total solubilisation to occur at $4^{\circ} \mathrm{C}$ for $1 \mathrm{~h}$, with occasional gentle mixing. 
8. After $1 \mathrm{~h}$ solubilisation, remove all remaining insoluble material by centrifugation $30,000 \mathrm{x} g$ for $10 \mathrm{~min}$ at $4^{\circ} \mathrm{C}$ (see Note 16).

9. Determine the protein concentration and adjust to $1 \mathrm{mg} / \mathrm{mL}$ by dilution in solubilisation buffer and proceed directly to re-folding at $4^{\circ} \mathrm{C}$ (Section 3.5).

\subsection{Protein Refolding.}

1. Dilute the solubilised proteins as quickly as possible (to yield a final protein concentration of $0.1 \mathrm{mg} / \mathrm{mL}$, see Note 17) into pre-chilled Refolding Buffer (see Note 18).

2. Dialyze the diluted solubilised protein overnight against a 200-fold volume of dialysis buffer with slowly decreasing concentrations of $\mathrm{GuHCl}$ (typically decrease $\mathrm{GuHCl}$ concentration as follows: $6 M, 4 M, 2 M, 1 M, 0.5 M$ and then 0 $M$ in a continual dialysis approach; see Fig. 1 and Notes 19, 20).

3. Centrifuge the dialysate at $4^{\circ} \mathrm{C}$ for $30 \mathrm{~min}$ at $30,000 \times \mathrm{g}$.

4. Carefully remove the liquid protein rich layer, concentrate (e.g. Amicon filtration) and store at an appropriate temperature (see Note 21). 


\section{Figure legend}

Figure 1: Schematic diagram of a simple gradient maker.

\section{Notes}

1. There are several methods to achieve this, including repeated freezing and thawing, sonication, homogenization at high pressures, enzymatic lysis or permeabilization by organic solvents. The method of choice depends on how fragile the protein is and how robust the host cell is.

2. Proteins can also be selectively released from the various compartments of a bacterial host, for example proteins expressed in the periplasmic envelope can be selectively lysed by a method similar to that described by French and co-workers (4). Pellet the bacterial cells to be disrupted by centrifugation at $800 \times g$ for 3 min. Resuspend the pellet in Fractionation Buffer (F1) buffer in $20 \%$ of the original culture volume. The F1 comprises (final concentrations): $500 \mu \mathrm{g} / \mathrm{mL}$ lysozyme, 20\% w/v sucrose, $1 \mathrm{~m} M$ EDTA, $\mathrm{pH} 8.0,200 \mathrm{~m} M$ guanidine hydrochloride and 200 $\mathrm{m} M$ Tris-HCl, $\mathrm{pH} 8.0$, at room temperature. Statically incubate the resuspended cells at room temperature for $15 \mathrm{~min}$, after which add an equal volume of ice-cold water. Stand the mixture at room temperature for $15 \mathrm{~min}$. Remove the cell debris by centrifugation at 10,400 x $g$ for $10 \mathrm{~min}$. Transfer the supernatant (containing the periplasmic fraction) to a clean container for further purification. 
3. Proteins expressed and transported to the culture supernatant can also be conveniently concentrated by a method outlined by Caldwell and Lattemann (5). In brief this method involves adding an equal volume of a PRMM solution $(0.05 \mathrm{~m} M$ pyrogallol red, $0.16 \mathrm{~m} M$ sodium molybdate, $1.0 \mathrm{~m} M$ sodium oxalate, $50.0 \mathrm{~m} M$ succinic acid, $20 \% \mathrm{v} / \mathrm{v}$ methanol in $\mathrm{H}_{2} \mathrm{O}$, adjusted to $\mathrm{pH} 2.0$ with $\mathrm{HCl})$ to cleared $(0.22 \mu \mathrm{m}$ filtered $)$ culture supernatant. Adjust the $\mathrm{pH}$ of the solution to $2.8( \pm 0.1)$, and allow the proteins to precipitate for 1 to $2 \mathrm{~h}$ at room temperature, followed by an overnight incubation at $4^{\circ} \mathrm{C}$. Sediment the precipitate by centrifugation at 10,000 $\mathrm{x} g$ for $1 \mathrm{~h}$, and carefully remove the supernatant. Repeatedly rinse the precipitate with $1 \mathrm{~mL}$ of acetone. Remove all traces of acetone by evaporation at room temperature. Solubilise the precipitate by adding $100 \mu \mathrm{L}$ of $2 \mathrm{x}$ sodium dodecyl sulfate-polyacrylamide gel electrophoresis (SDS-PAGE) sample buffer (25\% glycerol, $8 \%$ SDS, $4 \% \beta$-mercaptoethanol, $0.02 \%$ bromophenol blue, $100 \mathrm{mM}$ Tris- $\mathrm{HCl}, \mathrm{pH} 6.8$ ). These samples can be applied directly to an SDS-PAGE gel, if this type of analysis is required.

4. The sonication process can generate large amounts of heat, which is why pulses are limited to $\sim 20 \mathrm{~s}$. In between pulses, cool the tube in ice or ice-water slurry for $30 \mathrm{~s}$. If a large volume is required to be sonicated, split the cell suspension into two tubes, and alternate the sonication and cooling steps. Sonicate on ice where possible.

5. The extraction process also releases proteases, which will digest all proteins in the solution. If the protein is sensitive to proteolysis, it is desirable to employ a protease inhibitor (see Chapter 4), to proceed quickly, and to keep the extract cooled to minimise proteolysis.

6. Lysozyme ( $500 \mu \mathrm{g} / \mathrm{mL}$, to assist cell wall degradation) and DNase I ( $100 \mathrm{U} / \mathrm{mL}$, to degrade genomic DNA) can be added to the lysis buffer. 
7. The addition of high concentrations of salt to a protein solution causes precipitation by removing water from hydrophobic patches on the protein's surface, resulting in these patches aggregating together causing the protein to come out of solution. A number of salts can be used for this process; $\mathrm{NaCl}, \mathrm{Na}_{2} \mathrm{SO}_{4}, \mathrm{KCl}, \mathrm{CaCl}_{2}$ and $\mathrm{MgSO}_{4}$, however, $\left(\mathrm{NH}_{4}\right)_{2} \mathrm{SO}_{4}$ is by far the most commonly used additive. This is due to several advantageous characteristics of the salt, including the fact that it has a high solubility in water (4 $M$ saturation) and it has a low density at saturation allowing precipitated proteins to be collected by centrifugation. Hence the first proteins to be purified during ammonium sulphate precipitation are water-soluble proteins $(\boldsymbol{b})$.

8. Final concentrations of ammonium sulphate must be calculated using standard nomograms or with online tools (“Ammonium Sulfate Calculator", available at www.encorbio.com/protocols/AM-SO4.htm). Adding increasing amounts of ammonium sulphate causes the different fractions of a protein mixture to precipitate at different rates. One advantage of this method is that it can be performed inexpensively with very large volumes. Additionally, the high salt content of the precipitated protein permits its direct addition onto a hydrophobic interaction chromatography (HIC) purification column, thus speeding up the overall purification process.

9. Purification of integral membrane proteins requires the addition of a detergent such as sodium dodecyl sulphate ( $1 \%$ SDS) to dissolve cell membranes and keep membrane proteins in solution during purification. It should be noted that SDS causes protein denaturation, hence milder detergents such as $1 \%$ Triton X-100 or $1 \%$ CHAPS can be used to retain the protein's native conformation during cell membrane dissolution. 
10. Ammonium sulphate salt can be added either in saturated solution (as described above) or directly as salt crystals. It may be advantageous to add ammonium sulphate directly into the protein mixture as powdered solids during large scale purification processes so that the effect of dilution by the salt solution is minimized. If a saturated salt solution is employed the amount of ammonium sulphate solution added must be recorded accurately, often this is achieved by dispensing from a graduated pipette. It is critical to avoid the spatial non-uniformity in the salt concentration during the addition of the salt solution. Localized concentration "hot-spots" will prematurely initiate the precipitation of other proteins and inadvertently affect the precipitation process. Record the volume of the saturated ammonium sulphate solution required to precipitate the protein of interest. Also note that protein precipitation is not instantaneous; it may require 15 to $20 \mathrm{~min}$ to equilibrate.

11. TCA is a harmful skin and eye irritant. Always use correct personal protective equipment when handling it.

12. There are numerous options to effect other types of protein precipitation including (but not limited to) acetone precipitation (useful to simultaneously eliminate acetone soluble components and increase protein concentration), ethanol precipitation (useful to simultaneously concentrate proteins and remove traces of $\mathrm{GuHCl}$ prior to SDS-PAGE analysis), acidified acetone/methanol $(50 / 50 \mathrm{v} / \mathrm{v}$; useful to simultaneously remove acetone and methanol soluble interferences such as SDS prior to IEF analysis) and chloroform/methanol (50/50 v/v; useful to simultaneously remove salt and detergents).

13. The presence of trace amounts of TCA, carried through from the precipitation, can acidify the resuspension sample buffer. If further downstream processes are $\mathrm{pH}$ sensitive the sample 
buffer should be titrated with $1 M \mathrm{NaOH}$ or $1 M$ TrisHCl, $\mathrm{pH} 8.5$, to obtain the desired $\mathrm{pH}$ for the required process. Acidified SDS-PAGE sample buffer, for example, can give a yellow colour. Correct titration will result in reversion to the typical blue sample buffer colour. Hint: A simple method to overcome this is to resuspend the samples in a slightly basic SDS-PAGE loading buffer (e.g. pH 9.0). Hence, any residual TCA left it will be neutralized by the basic buffer allowing direct addition onto the SDS-PAGE gel. Additionally, excess TCA traces will cause the Coomassie dye to precipitate during SDS-PAGE. If this is a problem repeat the optional wash steps outlined.

14. The interactions between solvents and proteins, and also proteins and proteins, determine the solubility of any given protein. Interactions can be classified as either attractive or repulsive. A protein will be soluble in a particular solvent if the net free energy of the proteins interactions is adequately negative (i.e. attractive). Additionally, protein solubility is improved if proteinprotein interactions have sufficiently positive net free energy (i.e. repulsive), although it should be noted that protein-protein interaction is modulated by the chemical nature of the solvent of choice. Conversely, insolubility typically results from net attractive forces between proteins and net repulsive forces between the solvent of choice and the protein of interest. Furthermore, a soluble protein can be insolubilised by a change in it's free energy state in relation to the proteins, or the solvent, it interacts with and, hence, additions/subtractions to a protein solution should be carefully assessed on a small scale (7).

15. The separation of one protein, or family of proteins, from other proteins by means of differential solubility with chemical reagents is based on the differential solubility between a liquid phase and a solid phase. The optimisation of this procedure is empirical but, Lindwall and 
colleagues $(\boldsymbol{8})$ outline an optimisation procedure based on a sparse matrix approach; solubilisation buffers are composed based on "solubility space" which is related to accepted protein solubilisation theories. This method assists in identifying suitable solubilisation conditions for most over-expressed proteins.

16. It is important to remove existing aggregates that can act as nuclei to trigger aggregation during folding.

17. The final protein concentration should not exceed 0.05 to $0.1 \mathrm{mg} / \mathrm{mL}$ as dilute protein mixtures refold optimally at this concentration. A rapid and efficient mix is essential at this step.

18. The addition of a mild solubilising agent [e.g. $1 M$ 3(1-pyridinio)-1-propane sulfonate] during the refolding steps limits re-aggregation of re-folding proteins.

19. Continual dialysis can be set up by using a gradient maker. In its simplest form, this consists of two containers of the same shape connected by a siphon. One container contains the low concentration buffer, and the other contains high concentration buffer. The buffer is withdrawn from the low concentration container to the high concentration container. This will produce a linear gradient from high to low buffer concentrations over the total volume of the gradient. Once the "low concentration buffer" supply has been depleted, the dialysis tubing is removed from the larger vessel and placed in a similar, clean vessel containing fresh buffer at the same concentration as the original "low concentration buffer". The "low concentration buffer" vessel is replaced with a vessel containing buffer at the next lower concentration level and the process is allowed to continue until the "low concentration buffer" supply is depleted again. This process 
is repeated until the vessel containing the dialysis tubing has reached the desired final concentration, typically $0 \mathrm{M} \mathrm{GuHCl}$.

20. See Rudolph and Lilie (9) for a comprehensive overview of protein refolding and (10) for an industrial viewpoint on that topic.

21. Most proteins can be stored at $4^{\circ} \mathrm{C}$, without significant denaturation, for up to $24 \mathrm{~h}$. For intermediate storage times ( $24 \mathrm{~h}$ to one week) the protein should be filter sterilised (through a $0.22 \mu \mathrm{m}$ filter) and stored at $4{ }^{\circ} \mathrm{C}$. Additional supplements, such as a bacteriostatic agent (e.g. $0.1 \%$ sodium azide) can be included to avoid bacterial growth. For storage times greater than one week (up to several months) it is advisable to freeze the protein preparation. Rapid freezing helps reduce protein denaturation. It is useful to freeze the solution in small aliquots to avoid repeated freeze/thaw cycles which may reduce the biological activity of the protein. Additional stabilizing agents can also be added prior to freezing, such as glycerol $(5-50 \% \mathrm{w} / \mathrm{v})$, serum albumin $(10$ $\mathrm{mg} / \mathrm{mL}$ ), reducing agents (such as $1 \mathrm{mM}$ DTT), and ligands/co-factors (depending on the nature of the target protein). Extended protein storage (several months to years) should be carried out at $-80^{\circ} \mathrm{C}$ or in liquid nitrogen. The addition of $50 \%(\mathrm{w} / \mathrm{v})$ glycerol is recommended for storage at this temperature. Alternative strategies include storing the protein as an ammonium sulphate precipitate at $4{ }^{\circ} \mathrm{C}$, or at lower temperatures in a lyophilized form (see also Chapter $\mathbf{1 0}$ for protocols and discussion regarding the storage and lyophilisation of proteins). 


\section{References}

1. O’Fágáin, C. (1997) Protein stability and its measurement, in Stabilising protein function (Fágáin, C.O’., ed.), Springer Press, Berlin, pp 69-75.

2. Ramos, Y., García, Y., Llopiz, A., and Castellanos-Serra, L. (2008) Selectivity of bacterial proteome fractionation based on differential solubility: A mass spectrometry evaluation Anal. Biochem. 377, 134-140.

3. Leimgruber, R. M. (2005) Extraction and solubilisation of proteins for proteomic studies, in The Proteomics Protocols Handbook (Walker J. M., ed.), Humana, Totowa, NJ, pp 1-18.

4. French, C.; Keshavarz-Moore, E., Ward, J.M. (1996) Development of a simple method for the recovery of recombinant proteins from the E.coli periplasm. Enzyme Microb. Technol. 19, 3328.

5. Caldwell R.B., and Lattemann C.T. (2004) Simple and reliable method to precipitate proteins from bacterial culture supernatant. Appl. Environ. Microb. 70, 610-12.

6. Doonan, S. (2004) Bulk Purification by Fractional Precipitation, in Protein Purification Protocols, Methods in Molecular Biology (Cutler, P., ed.), Humana, Totowa, NJ, 244, pp 117125.

7. Rothstein F. (1994) Differential Precipitation of Proteins, in Protein Purification Process Engineering (Harrison, R. G. ed), Marcel Dekker Inc., NY, pp 115-16. 
8. Lindwall, G., Chau, M.-F., Gardner, S.R., and Kohlstaedt, L.A. (2000) A sparse matrix approach to the solubilisation of overexpressed proteins. Protein Eng. 13, 67-71.

9. Rudolph, R., and Lilie, H. (1996) In vitro folding of inclusion body proteins. FASEB 10, 4956.

10. Jungbauer, A., and Kaar, W. (2007) Current status of technical protein refolding. $J$. Biotechnol. 128, 587-96. 
Figure 1

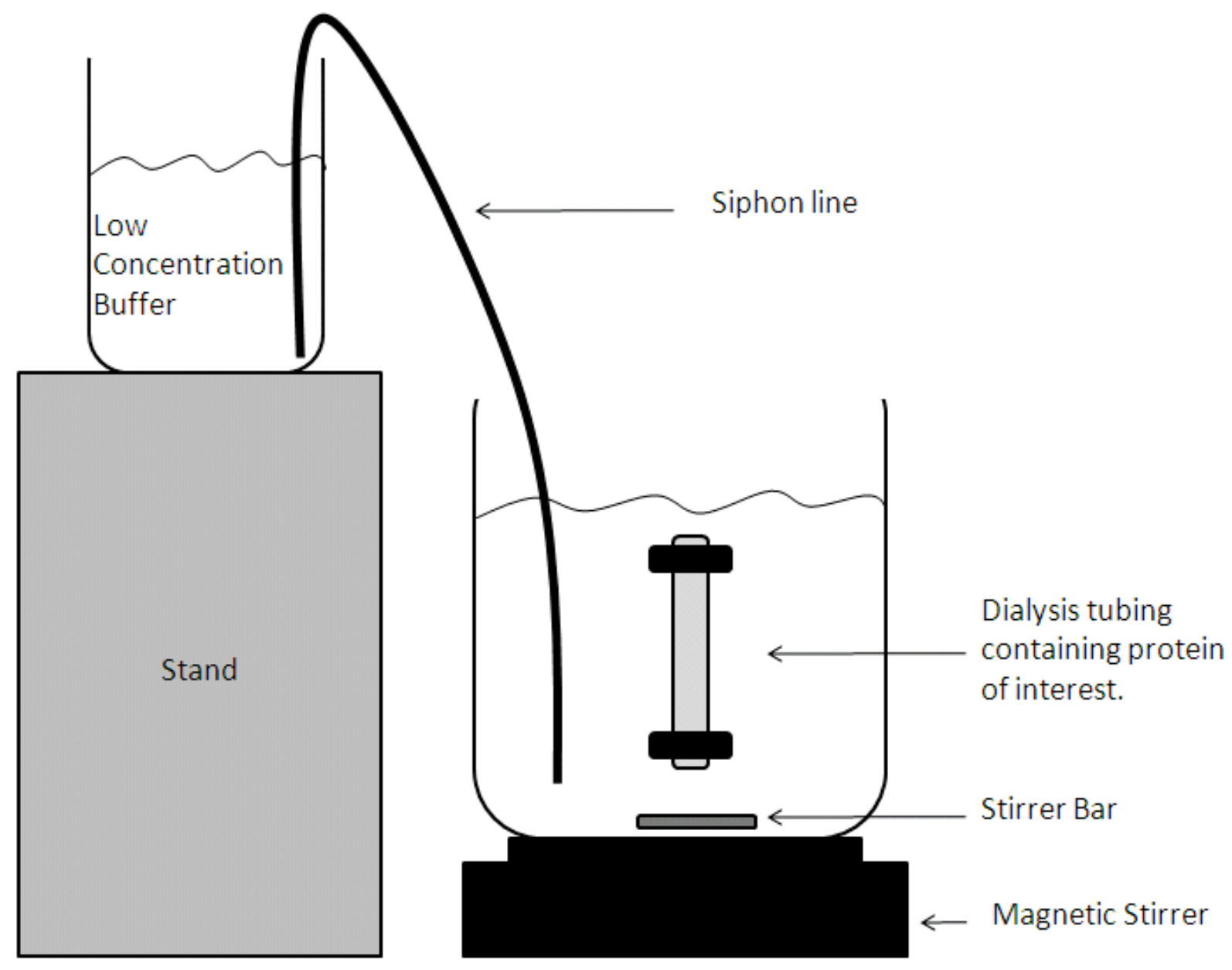

